\title{
Bacterial community composition and diversity uncovered in experimental sludge treatment reed bed systems with different swine slurry hydraulic loadings
}

\author{
Paula Arroyo ${ }^{\mathrm{a}}$, Luis E. Sáenz de Miera ${ }^{\mathrm{b}}$ *, Jorge Falagánc, Gemma Ansola ${ }^{\mathrm{a}}$ \\ a Departamento de Biodiversidad y Gestión Ambiental, Universidad de León, Campus de Vegazana s/n, CP: 24071 León, Spain \\ ${ }^{\mathrm{b}}$ Departamento de Biología Molecular, Universidad de León, Campus de Vegazana s/n, CP: 24071 León, Spain \\ ${ }^{c}$ Diputación de León, Servicio de Desarrollo Rural y Medio Ambiente, Complejo San Cayetano s/n 1ª planta, CP: 24071 León, Spain
}

\section{A R T I CLE INFO}

Keywords:

High-throughput sequencing

Bacterial communities

STRB

Swine slurry

Nitrogen cycle

\begin{abstract}
A B S T R A C T
Nowadays swine slurry management is a very important environmental issue. Sludge treatment reed bed systems are sludge treatment systems based on constructed wetlands.

The present study characterizes via 16S rRNA gene high-throughput the bacterial communities contained in untreated swine slurry and treated swine slurry by means of mesocosm-scale sludge treatment reed beds receiving different slurry loadings.

The bacterial community composition varied between the treated and untreated slurry, with a notable slurry loading influence also observed. Richness, diversity and ordination measurements of the studied communities evidenced profound differences between the untreated and treated swine slurry bacterial communities; and only slight differences among the treated swine slurry communities. Interestingly, the slurry loading allowed to define two groups: mesocosm communities residing in the highest hydraulic slurry loadings and other mesocosm communities. The $\mathrm{pH}$ value emerged as an important community composition, diversity and ordination predictor.

The functional bacterial community composition was predicted through the in silico approach. Results confirmed that the main nitrogen cycle metabolic pathways were present in the mesocosm communities with ammonification and assimilatory nitrate reduction as the most commonly detected nitrogen pathways in treated swine slurry.
\end{abstract}

\section{Introduction}

Wastewater treatment of pig farming persists an open-ended issue due to the high nutrient concentrations, in particular nitrogen compounds, and the limited land available to owners. Large swine sludge volumes are currently generated throughout the world, with estimates for Spain reaching approximately the 5600 million tonnes (Vázquez et al., 2013).

The implementation of the European Union's Nitrates and Water Framework Directives requires in general an adequate swine slurry treatment prior to land application. In this context, the limit of $170 \mathrm{~kg}$ of organic nitrogen/ha/annum imposed by the Nitrates Directive can cause severe difficulties for wastewater management in the pork industry (Harrington et al., 2012).

Sludge treatment reed bed systems (STRBs), also known as sludge drying wetlands and planted dewatering beds are composed of porous media that are planted with emergent macrophytes. These constructed wetlands have been used in Europe for sludge treatment since 1988 when the first sludge processing system was introduced in Denmark (Nielsen and Larsen, 2016). They are loaded with layers of sludge and the long-term sludge reduction takes place partly due to dewatering (draining, evapotranspiration) and partly due to the mineralization of the organic matter present in the sludge. Pathogen removal from domestic and swine wastewater is also achieved in these treatment sys-

\footnotetext{
* Corresponding author.

Email addresses: paula.arroyo@unileon.es (P. Arroyo); luis.saenzdemiera@unileon.es (L.E.Sáenz de Miera); jorge.falagan@dipuleon.es (J. Falagán); gemma.ansola@unileon.es (G.
} Ansola) 
tems (Nielsen, 2007; Molleda et al., 2008; Giácoman-Vallejos et al., 2015).

They provide substantial environmental, economic, and operational benefits compared to mechanical sludge dewatering solutions such as belt presses and centrifuges (Nielsen and Larsen, 2016). Nevertheless, they possess also the following disadvantages: large areas are occupied; high dependence on local climate; secondary pollution of groundwater is caused (Xian et al., 2010). In order to avoid secondary pollution of groundwater problems the basins should be built with a liner as a standard (Nielsen, 2003).

Bacterial communities are integrally involved in the biogeochemical cycles and their activities are crucial to the natural (Ahn and Peralta, 2009; Peralta et al., 2013) and constructed wetland (Ahn et al., 2007) functions because they play a critical role in the energy flow and nutrient transformation. Knowledge of the bacterial community composition is important to understand their waste degradation function allowing to develop better strategies to manage and use stored sludge (Bunton et al. 2007).

The currently available high-throughput sequencing (using $16 \mathrm{~S}$ rRNA genes) of environmental DNA allows for a rapid microbial community analysis at a much higher output than has previously been possible (Inceoğlu et al., 2011). Recent use of this tool has provided an increasing amount of knowledge about the bacterial community structure in different ecosystems (Ansola et al., 2014 and references therein). However, this molecular tool does not provide direct evidences of the bacterial community functional capabilities. In this context, Langille et al. (2013) described a computational approach, named PICRUSt, to predict the functional composition of a metagenome using marker gene data and a database of reference genomes.

The present study assessed usage of sludge treatment reed bed system to treat swine slurry. Specifically, owing to the bacterial community importance to remove nutrients, three objectives were established: (i) to determine the composition and structure of the untreated and treated swine slurry bacterial communities present in the experimental mesocosms; (ii) to examine the environmental effects (hydraulic loading, zones within the mesocosm) in relation to the bacterial community structure and composition; (iii) and to assess the functional composition of the communities focused on the nitrogen cycle.

\section{Material and methods}

\subsection{Experimental set up and operational conditions of the sludge treatment wetlands}

Three mesocosm-scale STRBs were established in an open-air laboratory at the University of León (Spain). All mesocosms consisted of an experimentation tank made out of fiberglass with a dimension of

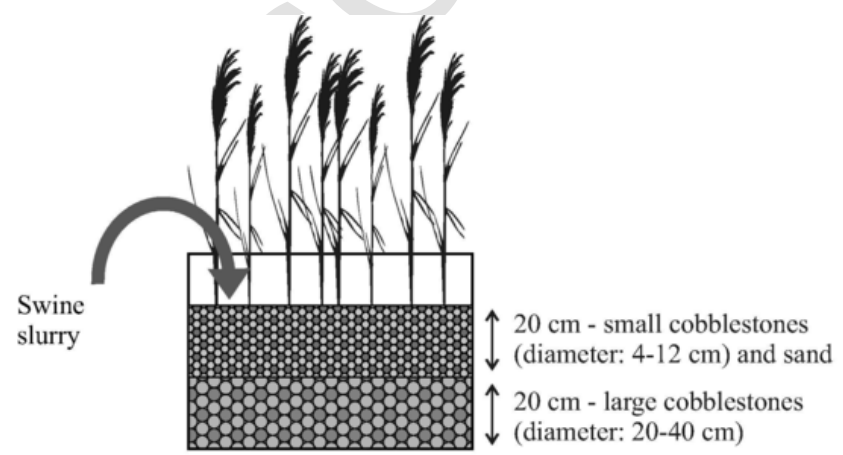

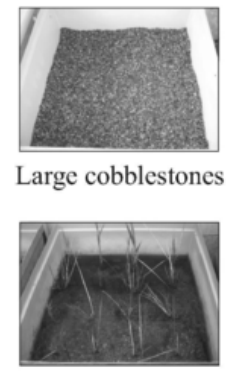

Phragmites australis
$120 \mathrm{~cm}$ long, $120 \mathrm{~cm}$ wide and $50 \mathrm{~cm}$ high. To improve the resolution of the study, two replicates per mesocosm were operated for a period of 12 months.

The STABs were filled from top to bottom with two different substrates, a $20 \mathrm{~cm}$ layer of sand and small cobblestones (diameter $4-12 \mathrm{~cm}$ ), and a $20 \mathrm{~cm}$ layer of large cobblestones (diameter $20-40 \mathrm{~cm}$ ) in order to create the filter matrix of each mesocosm. A spillway was installed in order to collect the leachate.

Plant density comprises an important factor and planting rates can vary from four plants per $\mathrm{m}^{2}$ to twelve plants per $\mathrm{m}^{2}$ (Edwards et al. 2001). In the present experiment, plants (Phragmites australis) were collected from watercourses located in the vicinity of the laboratory at the University of León and planted in September. Eleven plants per $\mathrm{m}^{2}$ were placed in each STRB (Fig. 1).

The operation cycle consisted of a start-up phase, in which as suggested by Kengne et al. (2011), mesocosms were irrigated with untreated wastewater during six months (October to March). The second phase was performed by mesocosm loading once a week during four months (April to July). Loading frequency was chosen according to other studies (Giraldi and Iannelli, 2009; Stefanakis and Tsihrintzis, 2012). During this phase, the prevailing dry and hot climatic conditions required to retain the leachate in the mesocosms in order to avoid plant wilting and dying off. Finally, wetlands were left the last month without additional loadings.

The swine slurry was derived from a pig farm belonging to University of León (50 sows). Before wetland loading, sludge was discharged into a holding-mixing tank. Although treatment of farm effluents in constructed wetlands has usually required the application of pre-treatment operations (Vázquez et al., 2013), in the present experiment, slurry was directly applied in one sludge treatment reed bed mesocosm (STRB-0A) and its replicate (STRB-0B) with a slurry hydraulic loading of $1.00 \mathrm{~m}^{3} \mathrm{~m}^{-2}$ year. As to the other mesocosms, the swine slurry was previously diluted and then applied with a hydraulic slurry loading in each mesocosm pair of $0.50 \mathrm{~m}^{3} \mathrm{~m}^{-2}$ year (STRB-1A and STRB-1B) and $0.25 \mathrm{~m}^{3} \mathrm{~m}^{-2}$ year (STRB-2A, STRB-2B). These loadings approximately correspond to 80,40 and $20 \mathrm{~kg} \mathrm{DS} \mathrm{m}^{-2}$ year, respectively.

\subsection{Sample collection and analysis}

Before of the swine slurry application, the untreated swine slurry was analysed four times with respect to a physico-chemical characterization and once with regard to a bacterial community characterization.

Treated swine manure samples were collected using a push core sampler ( $\varnothing 5.3 \mathrm{~cm}$, length of $100 \mathrm{~cm}$ ). This sampling was conducted at the end of the experiment for the physico-chemical characterization and for the bacterial community characterization (Fig. 2). Treated swine slurry samples $(0-2 \mathrm{~cm}$ in depth) were collected from two differ-

Sludge treatment reed bed mesocosm: L 120 x W 120 x H $50(\mathrm{~cm})$



Six mesocosm-scale sludge treatment reed beds






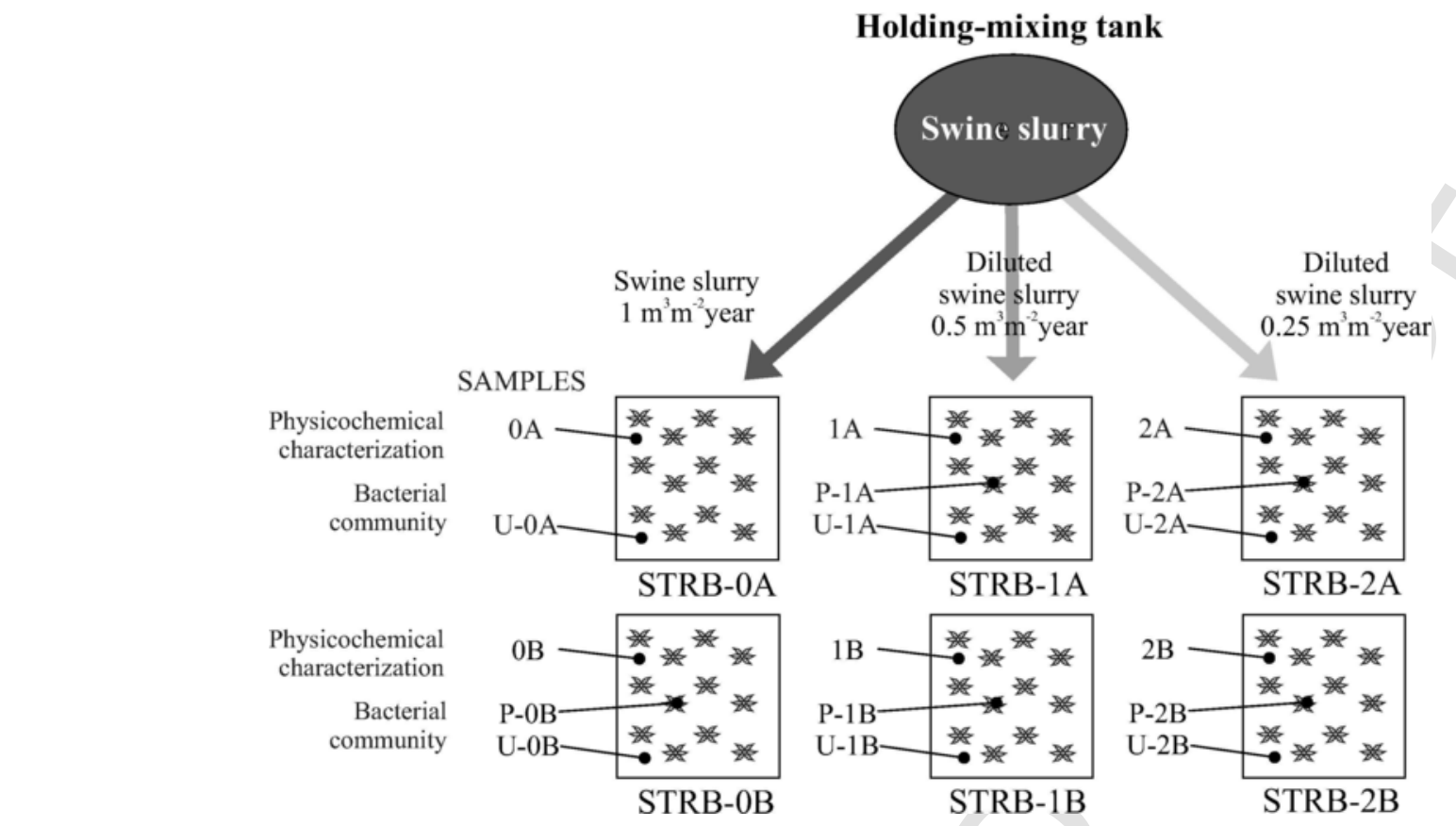

\section{Holding-mixing tank}


mesocosm replicates.

ent environments in each mesocosm: the Phargmites australis zone (P) and the unplanted zone (U). Three replicates were taken for each sample. In the laboratory the three replicates were mixed and homogenized for each sample. Once mixed, a subsample was taken for the bacterial community analysis, and the remainder was used for the manure characterization (with exception of the STRB-A1 mesocosm for which the bacterial community analysis was only performed for the unplanted zone).

To characterize the untreated swine slurry, the liquid and solid fractions were analysed separately. Organic matter (SOM), humidity, $\mathrm{pH}$, total Kjeldahl nitrogen (TKN), ammonia nitrogen $\left(\mathrm{NH}_{4}{ }^{+}-\mathrm{N}\right)$ and nitrate nitrogen $\left(\mathrm{NO}^{3-}-\mathrm{N}\right)$ were analysed for all manure samples and also for the slurry solid fraction, using the standard protocols of the Spanish Ministry of Agriculture, Fisheries and Food (Ministerio de Agricultura, Pesca y Alimentación, 1994). Moreover, the total Kjeldahl nitrogen and ammonia nitrogen were also analysed in the liquid slurry fraction, according to the protocols included in the standard methods for water and wastewater (APHA, 2005).

\subsection{DNA extraction, PCR and pyrosequencing}

Prior to DNA extraction, the untreated swine slurry was centrifuged at $5000 \mathrm{rpm}$ for $10 \mathrm{~min}$. The Power Soil DNA isolation kit (MoBio Laboratories, Inc., Carlsbad, CA, USA) was used with $0.25 \mathrm{~g}$ of centrifuged untreated samples and non-centrifuged treated swine samples.

For each sample, one different $8 \mathrm{bp}$ forward barcoded primer was linked to the pyrosequencing adaptor A of Roche 454 and to the bacterial primer "AYTGGGYDTAAAGNG" (E. coli positions 563-577). The reverse primer was common to all samples and was composed of four variants targeting the same 16S rRNA region "TACNVGGGTATCTAATCC", "TACCRGGGTHTCTAATCC", "TACCAGAGTATCTAATTC", and "CTACDSRGGTMTCTAATC" (E. coli positions 785-802) linked to the pyrosequencing adaptor B of Roche 454 . These primers amplify the $16 \mathrm{~S}$ rRNA V4 region and have been designed and recommended by the Ribosomal Database Project (RDP) of Michigan State University (Cole et al., 2008).
The PCR reaction mixture contained $1 \mu \mathrm{M}$ of each primer, $1.8 \mathrm{mM}$ $\mathrm{MgCl}_{2}, 0.2 \mathrm{mM}$ dNTPs, $1.5 \times$ BSA (New England Biolabs), 1 unit of FastStart High Fidelity PCR system enzyme blend (Roche Applied Science) and $100 \mathrm{ng}$ of DNA template in a $30 \mu \mathrm{l}$ final volume. Amplification was carried out in an Applied Biosystems thermal cycler (Model Gene Amp PCR System 9700). Amplification conditions were as follows: $3 \mathrm{~min}$ at $95^{\circ} \mathrm{C}, 30$ cycles of $95^{\circ} \mathrm{C}$ for $45 \mathrm{~s}, 57^{\circ} \mathrm{C}$ for $45 \mathrm{~s}$, and $72^{\circ} \mathrm{C}$ for $60 \mathrm{~s}$ and a final $4 \mathrm{~min}$ incubation at $72^{\circ} \mathrm{C}$ to complete the extension process.

Agencourt AMPure XP System (Beckman Coulter, Inc., CA, Brea, USA) as recommended in the instructions of the manufacturer was used to purify a pool of three independent PCR products of each sample. Quantification of the purified PCR products was undertaken with PicoGeen (Invitrogen, Carlsbad, CA, USA). Amplicons were subjected to pyrosequencing using a Roche GS Flx system using the vendor's specified chemicals, sequencing from the A adaptor only.

\subsection{Data analysis}

Reads with a length of less than $200 \mathrm{bp}$ and ambiguous sequences were screened and removed from the samples using the Mothur (version 1.39.5) recommended procedure (Scholss et al., 2009). Unique sequences were determined with Mothur. Sequence reads were assigned to taxonomic groups using the NaïveBayesian rRNA classifier tool (Wang et al., 2007) of the Ribosomal Database Project (Cole et al., 2014) with a confidence threshold of $50 \%$ cut off (default value) for each taxonomic unit (from phylum to genus). Chimeras were removed using UCHIME (Edgar et al., 2011) as implemented by QIIME (version 1.9.1) (Caporaso et al., 2010). Unique sequences were clustered into operational taxonomic units (OTUs) by UCLUST (Edgar, 2010) based on a 97\% pairwise identity using QIIME; and OTUs with less than four reads were removed. Alternatively OTUs were obtained without reference in order to perform the ecological diversity indexes, or with reference, using the Greengenes database (13_8 release) (McDonald et al., 2012), in order to generate an in silico metagenome using PICRUSt (Langille et al., 2013). 
A multiple alignment and a phylogenetic tree were constructed using MEGA7 (Kumar et al., 2016) to support the calculations of the Unifrac and Weighted Unifrac metrics (Lozupone and Knight, 2005). Alfa and beta diversities (including Unifrac) were conducted using Mothur and the Vegan package v.2.4.3 (Oksanen et al., 2010) in R software (R Core Team, 2016). To compare diversity between samples, a principal coordinate analysis ( $\mathrm{PCoA}$ ) based on the pairwise community distances was calculated using the Ape package of R v.3.2.1 (Paradis et al., 2004). The correspondence (CA) and the constrained correspondence analyses (CCA) ordination methods, also included in the Vegan package, were used to explore the bacterial community beta diversity. Whereas the CA is an indirect gradient analysis, the environmental gradients can be inferred from the taxa composition data (Palmer, 1993). The effects of the environmental variable over the bacterial community ordination was explored by comparing the CA and the CCA models with a permutation test or by using the MANOVA permutation test of the distance matrices, also implemented in Vegan package.

The metagenome obtained in silico using the PICRUSt software provides a quantitative list of genes in reference to the Kyoto Encyclopedia of Genes and Genomes (KEGG) pathway database for each generated metagenome (www.genome.jp/kegg/pathway.html). Nitrogen metabolism gene orthologs were used to compare the functional behaviour of the analysed microbial communities.

Other basic statistical tests (descriptive statistics; Kruskal-Wallis test) were also performed using the R software. Significance differences were defined at $\mathrm{p}<0.05$.

\section{Results and discussion}

\subsection{Physico-chemical characterization}

The physico-chemical parameters of the untreated swine slurry and of the manure obtained are displayed in Table 1. Significant differences $(\mathrm{p}<0.005)$ were observed with respect to all five parameters between the untreated slurry and the manure obtained from the different wetlands. However, no significant differences were detected among the wetlands.

Plants showed no stress symptoms in neither mesocosm after loadings; the only significant exceptions were both mesocosms receiving non-diluted slurry, evidencing the Phragmites australis plants visual phytotoxicity signs; particularly one of the two replicates (OA) in which most of the plants died. As reported by Calheiros et al. (2007), ammonia nitrogen concentrations of $400 \mathrm{mgL}^{-1}$ to $500 \mathrm{mg} \mathrm{L}^{-1}$ amply exceed the aquatic plant tolerance limiting plant survivorship. The final height of the accumulated sludge residue varied between five and ten $\mathrm{cm}$.

Regarding the bacterial communities, it is important to remark the $\mathrm{pH}$ value decrease of the untreated swine slurry compared to the manure obtained. Different studies about bacterial community shifts in relation to soil properties have revealed that the soil $\mathrm{pH}$ represents the strongest known bacterial community composition and diversity soil predictor (Bartram et al., 2014; Sáenz de Miera et al., 2016). In partic- ular, the relationship between the $\mathrm{pH}$ and the bacterial community structure in pig manure slurry was described by Kumari et al. (2015).

The high untreated slurry sample $\mathrm{pH}$ value could imply alkaliphilic bacterial presence, that is, microbes subsisting well at $\mathrm{pH}$ values of around 9. The ecological niches of the alkaliphilic bacteria are remarkably diverse, e.g., ranging from alkaline soda lakes, the hind-gut of insects, to soils subject to ammonification and human industrial processes that generate high pH values (Preiss et al., 2015).

\subsection{Phylum-level taxonomic distribution}

A total of 215,479 bacterial sequences were obtained from the 12 samples through pyrosequencing analysis. Each library contained 13,825 (U-2B) to 29,208 reads (U-1B). When necessary, reads counts were normalized to 10,000 .

The most abundantly detected phyla in the untreated slurry sample were Firmicutes (43\%), Proteobacteria (18\%), Spirochaetes (12\%), Verrucomicrobia (8\%), Bacteroidetes (6\%), and Tenericutes (3\%). The bacterial phylum composition determined in this study is in agreement with that reported in several previous studies on swine slurry (Cook et al., 2010; Isaacson and Kim, 2012; Hwang et al., 2014; Kumari et al., 2015), with the only exception of the Bacteroidetes phylum's under-representation. The bacterial phyla Firmicutes and Bacteroidetes are known to dominate the pig gastrointestinal tract (Isaacson and Kim, 2012; Hwang et al., 2014). Nevertheless it must be considered, as reported by Snell-Castro et al. (2005), that several highly represented phylotypes in the pig gastrointestinal tract endure which are under-represented within of the swine slurry.

Influence of the treatment on the slurry bacterial community composition is observed by comparing samples (Fig. 3). The bacterial community in the untreated slurry was amply dominated by the phylum Firmicutes, phylotypes belonging to the order Clostridiales (78\%) accounted for the majority of the classified OTUs. In contrast, the Proteobacteria contributed to the greater part of the community composition of all the treated slurry samples, ranging between 47 and $51 \%$ in the P. latifolia zone (P), and between 40 and $45 \%$ in the unplanted zones (U).

Remarkable also the notable Spirochaetes reduction, since in the untreated sample the phyla accounted for $12 \%$ whereas its presence decreased to an average of $0.6 \%$ in the treated samples. Reduction was mainly linked to the genus Treponema, which contains both pathogenic and nonpathogenic species. A Tenericutes phyla reduction was also observed, accounting the genus Acholeplasma for the majority.

Within the Proteobacteria phylum, five classes $(\alpha, \beta, \gamma, \delta$ and $\varepsilon$ ) were represented in all slurries. Nevertheless, in the untreated slurry OTUs classified as $\gamma$-Proteobacteria (51\%) accounted for the majority of the Proteobacteria and only $3 \%$ of the OTUs were classified as $\alpha$-Proteobacteria. By contrast, in the treated samples the presence of $\gamma$-Proteobacteria gradually decreased based on the hydraulic slurry loading, ranging between 42 and $31 \%$ in the $P$. australis zones (P-0: $1.00 \mathrm{~m}^{3} \mathrm{~m}^{-2}$ year; P-2: $0.25 \mathrm{~m}^{3} \mathrm{~m}^{-2}$ year, respectively), and between 34 and $25 \%$ in

Table 1

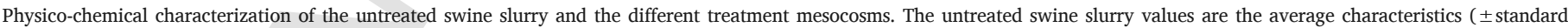

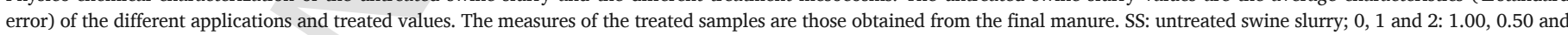
$0.25 \mathrm{~m}^{3} \mathrm{~m}^{-2}$ year, respectively; A and B: mesocosm replicates.

\begin{tabular}{|c|c|c|c|c|c|c|c|}
\hline Swine slu & & $\mathrm{pH}$ & Humidity (\%) & Organic matter (\%) & TKN (mg N Kg $\left.{ }^{-1}\right)$ & $\mathrm{NH}_{4}^{+}\left(\mathrm{mg} \mathrm{N} \mathrm{Kg}^{-1}\right)$ & $\mathrm{NO}^{3-}\left(\mathrm{mg} \mathrm{N} \mathrm{Kg}^{-1}\right)$ \\
\hline \multicolumn{2}{|c|}{ Untreated (SS) } & $8.73 \pm 0.47$ & $92.37 \pm 0.97$ & $73.65 \pm 13.72$ & $7789.64 \pm 623.38$ & $6034.44 \pm 1306.01$ & - \\
\hline \multirow[t]{6}{*}{ Treated } & $\mathrm{OA}$ & $8.11-2$ & 11.40 & 83.75 & 1316.88 & 20.76 & 96.31 \\
\hline & $\mathrm{OB}$ & 8.21 & 19.06 & 82.85 & 2464.78 & 28.24 & 169.45 \\
\hline & $1 \mathrm{~A}$ & 7.37 & 15.20 & 45.52 & 1726.22 & 74.53 & 66.60 \\
\hline & $1 \mathrm{~B}$ & 7.36 & 17.40 & 49.39 & 1679.60 & 43.95 & 491.64 \\
\hline & $2 \mathrm{~A}$ & 7.67 & 14.40 & 62.85 & 1564.53 & 118.76 & 294.70 \\
\hline & $2 \mathrm{~B}$ & 7.30 & 17.80 & 77.62 & 1423.22 & 76.89 & 68.71 \\
\hline
\end{tabular}



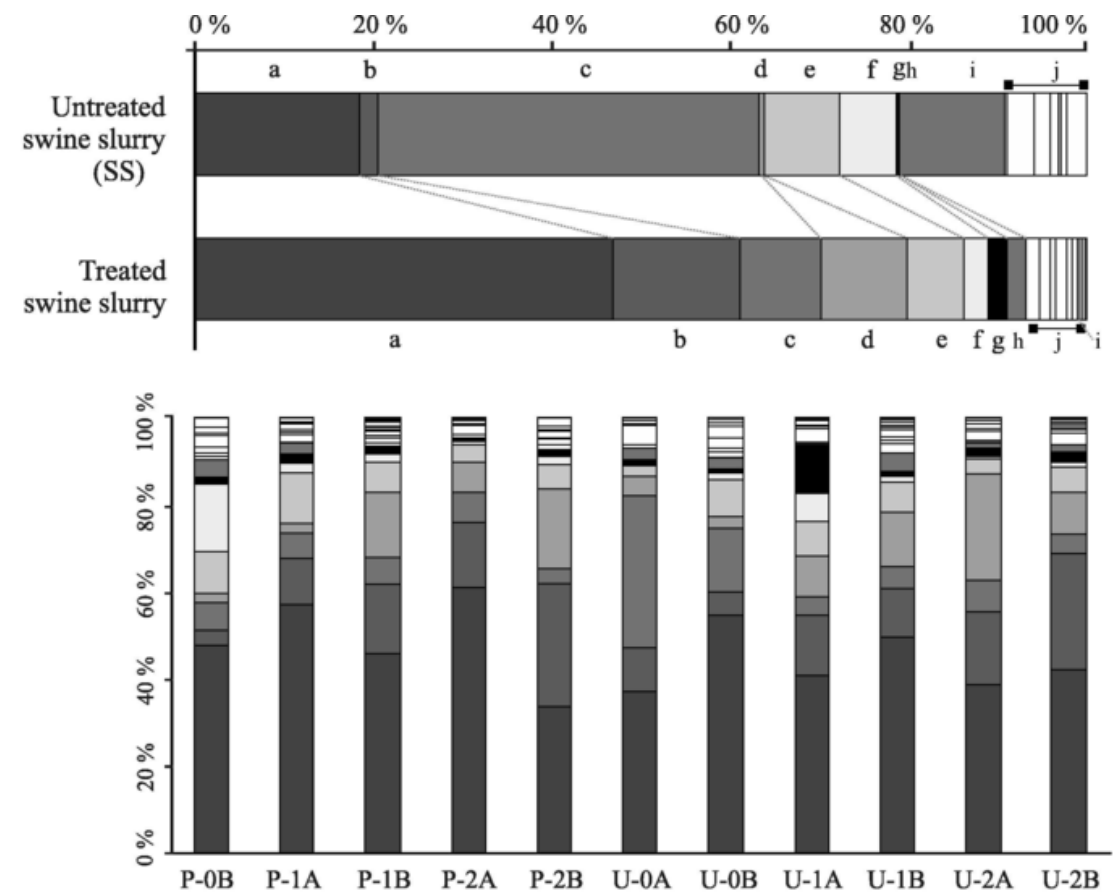

a: Proteobacteria; b: Acidobacteria; c: Firmicutes; d: Chloroflexi; e: Verrucomicrobia; f: Bacteroidetes; g:Planctomycetes; h: Deinococcus-Thermus; i: Spirochaetes; j: other Phyla (20).

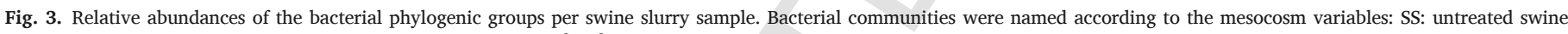

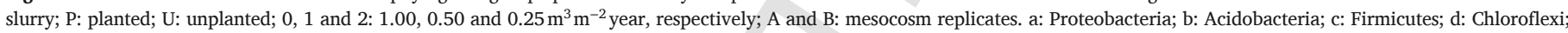
e: Verrucomicrobia: f: Bacteroidetes; g: other phyla.

the unplanted zones (S-0; S-2, respectively). The presence of the $\alpha$-Proteobacteria also followed a hydraulic slurry loading tendency. In the $P$. australis zones an increment was observed that ranged between 30 and $44 \%$ (P-0, P-2); whereas in the unplanted zones it varied from 44 to $40 \%$ (S-0, S-2, correspondingly).

Interesting in the present study the $\gamma$-Proteobacteria class was amply dominated by the Ruminobacter sp. (originally classified within the Bacteroidetes phylum) and the Succinivibrio sp. (47 and 52\%, respectively) in the untreated slurry.

\subsection{Alpha diversity measurements}

Reads were grouped into OTUs using a 0.97 identity cluster analysis. The OTUs obtained were used to estimate the bacterial community Alpha diversity (Table 2).

The Chao 1 estimator of the untreated swine slurry bacterial community (SS) presented the lowest richness, followed by those mesocosm communities which received the highest hydraulic slurry loadings $\left(1.00 \mathrm{~m}^{3} \mathrm{~m}^{-2}\right.$ year STW-0), afterwards the bacterial communities belonging to those mesocosms with hydraulic slurry loadings of 0.50 and $0.25 \mathrm{~m}^{3} \mathrm{~m}^{-2}$ year (STRB-1 and STRB-2, respectively).

Table 2

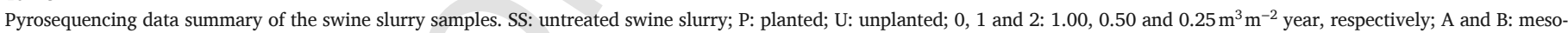
cosm replicates.

\begin{tabular}{|c|c|c|c|c|c|c|c|}
\hline \multirow[t]{2}{*}{ Samples } & \multirow[t]{2}{*}{ Number of reads } & \multirow[t]{2}{*}{ Number of OTUs } & \multirow[t]{2}{*}{ Good's coverage } & \multicolumn{2}{|c|}{ Richness estimator (lci-hci) } & \multicolumn{2}{|c|}{ Alpha diversity indices (lci-hci) } \\
\hline & & & & Chao 1 & ACE & Shannon-Weaver's & Simpson \\
\hline SS & 12,975 & 473 & 92.31 & $496.2-561.4$ & $495.2-485.4$ & $4.90-4.95$ & $0.014-0.015$ \\
\hline $\mathrm{P}-\mathrm{OB}$ & 15,092 & 1109 & 84.37 & $1306.2-1465.6$ & $1364.8-1311.4$ & $5.74-5.79$ & $0.007-0.007$ \\
\hline P-1A & 14,594 & 1139 & 82.75 & $1345.1-1504.3$ & $1364.9-1495.0$ & $5.65-5.70$ & $0.009-0.010$ \\
\hline P-1B & 13,081 & 1566 & 82.31 & $1820.5-1993.4$ & $1790.4-1905.6$ & $6.42-6.47$ & $0.004-0.004$ \\
\hline $\mathrm{P}-2 \mathrm{~A}$ & 21,242 & 1540 & 82.78 & 1805.4-1981.5 & $1808.4-1940.5$ & $5.69-5.74$ & $0.013-0.014$ \\
\hline P-2B & 17,047 & 1535 & 83.97 & $1783.8-1959.2$ & 1749.5-1862.9 & $6.04-6.10$ & $0.009-0.10$ \\
\hline S-0A & 19,349 & 1157 & 82.87 & $1371.8-1538.8$ & 1367.9-1489.4 & $5.10-5.16$ & $0.022-0.024$ \\
\hline S-OB & 15,905 & 983 & 85.49 & $1132.3-1267.7$ & $1148.6-1258.0$ & $5.53-5.57$ & $0.008-0.009$ \\
\hline S-1A & 14,245 & 1153 & 84.02 & 1795.5-1966.9 & $1763.8-1875.2$ & $6.41-6.46$ & $0.004-0.004$ \\
\hline$S-1 B$ & 28,105 & 1546 & 88.05 & $1768.8-1935.7$ & $1738.2-1845.6$ & $6.00-6.04$ & $0.006-00.67$ \\
\hline$S-2 A$ & 13,385 & 1191 & 80.73 & $1391.0-1543.8$ & $1403.5-1523.0$ & $5.71-0.01$ & $0.010-0.011$ \\
\hline S-2B & 17,996 & 1540 & 84.53 & $1728.3-1861.7$ & 1779.7-1902.6 & $6.17-6.22$ & $0.005-0.006$ \\
\hline
\end{tabular}


Regarding Shannon-Weaveŕs diversity index, the bacterial communities in the treated swine slurry samples presented higher diversity values than the untreated slurry. Results are in accordance with the Simpson's index values which exhibited the highest values indicating a lower community diversity of the untreated swine slurry.

The overall bacterial community composition pattern was also observed using the diversity measurements indicating profound differences between the untreated (SS) and treated swine slurry bacterial communities and slight differences among the treated swine slurry bacterial communities. For these last it was possible to identify two groups: 1-bacterial communities from mesocosms receiving the highest hydraulic slurry loadings (STRB-0) and 2-communities derived from the other mesocosms (STRB-1 and STRB-2).

\subsection{Bacterial community comparisons}

Principal coordinates analysis (PCoA) was performed with the distance matrix based on three indexes: the quantitative weighted Unifrac metric (Fig. 4A), the qualitative unweighted Unifrac metric (Fig. 4B) and the Chao dissimilarity index (Fig. 4C). Whereas the Chao index is a classical ecological abundance-based dissimilarity index, the Unifrac metric provides a more robust index of the community phylogenetic distances.

All PCoA analyses revealed the same overall pattern since the untreated slurry community was clearly separated from the other bacterial communities. Quantitative Unifrac PCoA (Fig. 4A) clearly distinguished two groups located on axis 1 (treated and untreated swine slurry communities) whereas the communities belonging to the planted and the unplanted zones tended to be grouped together on axis 2 . Moreover, microbial communities located in the planted zones seemed to be more related than those sampled in the unplanted zones.

Qualitative Unifrac PCoA substantiated similar results (Fig. 4B), although the untreated swine slurry was separated by the joint axis 1 and 2 effects, and the communities belonging to the planted and the unplanted zones were clearly grouped together along axis 1 .

Considering the Chao dissimilarity index, the first axis explained a much higher proportion of the variance (45.2\%) than those analyses based on the phylogenetic distances. The untreated bacterial community sample clearly separated from all of the other communities. Moreover, it was possible to identify a gradient along of axis 1 according to the hydraulic loadings (Fig. 4C).

A correspondence analysis (CA) was performed and Fig. 5 shows the ordination diagram obtained representing communities from the treated slurry samples, the OTUs, and the environmental variables. The first two CA axes accounted for $36.1 \%$ of the total bacterial community structure variation. The angle of the vectors indicated that two environmental variables (dilution or hydraulic slurry loading factor and $\mathrm{pH}$ ), were closely related with the CA1 axis. This axis allowed to form two groups by splitting up those communities derived from mesocosms which received a slurry hydraulic loading of $1.00 \mathrm{~m}^{3} \mathrm{~m}^{-2}$ year (P-0 and $\mathrm{S}-0$ ) from those belonging to the mesocosms receiving slurry hydraulic loadings of 0.50 or $0.25 \mathrm{~m}^{3} \mathrm{~m}^{-2}$ year (P-1 and S-1; P-2 and S-2).

In order to deepen knowledge on the bacterial community ordination environmental effects, Correspondence models constrained to environmental variables (CCA) were performed and compared with the CA models obtained through an ANOVA permutation test. In addition, a permutation multivariate variance analysis, analogous to a MANOVA, was performed with the distance matrices between samples of the mesocosms (Table 3).

Regarding the hydraulic loading factor, significant differences were observed when CCA was constrained by this variable $(P<0.001)$. Significant differences were also detected through the MANOVA analysis performed with the quantitative indices (Weigthed-Unifrac $\mathrm{P}=0.045$ and Morisita-Horn, $\mathrm{P}=0.004$ ). These results suggest that the hydraulic loading determined the relative abundance of the OTUs more than the presence or absence of those OTUs.

As already commented, different studies have revealed the soil $\mathrm{pH}$ influence on the bacterial community composition and diversity. In this context, significant differences were detected upon comparing the $\mathrm{CA}$ and the CCA constrained with $\mathrm{pH}(\mathrm{P}=0.004)$, also through the MANOVA performed by the Morisita-Horn index $(\mathrm{P}=0.002)$. The slurry $\mathrm{pH}$ variable mainly influenced the composition and diversity in relation to the relative abundance of some OTUs.

All these results statistically supported those related to the influence of the $\mathrm{pH}$ and the hydraulic load in shaping the community ordination into two groups, that is, those that received $1.00 \mathrm{~m}^{3} \mathrm{~m}^{-2}$ year of slurry (P-0 and S-0) compared to those that received slurry loadings of 0.50 or $0.25 \mathrm{~m}^{3} \mathrm{~m}^{-2}$ year (P-1 and S-1; P-2 and S-2).

The effects of the variable sampling zone (Phargmites australis (P), unplanted (U)) were also studied. Significant differences were detected through the MANOVA analysis performed with the Unifrac measurements $(P=0.034$ and $P=0.008)$ and the Chao index $(P=0.039)$. That is to say, the presence or absence of bacterial community OTUs was significantly affected by the sampling zone. By contrast, this variable did not influence the relative abundance of the OTUs.

Regarding the other variables studied, the influence of the total Kjeldahl nitrogen was remarkable. Significant differences were observed between the CA and the CCA constrained with the TKN variable $(\mathrm{P}=0.029)$ in addition to the MANOVA analysis performed with the Chao $(P=0.002)$ and the Morisita-Horn $(P=0.018)$ indices.


Untreated swine slurry (SS):

Mesocosm sample Planted (P):

Mesocosm sample Unplanted (S):

Slurry hydraulic loading of mesocosms: $1 \mathrm{~m}^{3} \mathrm{~m}^{-2}$ year $(0)$

$0.5 \mathrm{~m}^{3} \mathrm{~m}^{-2}$ year $(1) \bigcirc \quad 0.25 \mathrm{~m}^{3} \mathrm{~m}^{-2}$ year $(2) \bigcirc$

Fig. 4. Principal Coordinates Analysis (PCoA) plots derived from pairwise Unifrac distances (A and B) and Morisita-Horn (C) among the swine slurries. SS: untreated swine slurry. 




Mesocosms sample Planted $(\mathrm{P})$ :

Mesocosms sample Unplanted (S):

OTUs: +

Slurry hydraulic loading of mesocosms: $1 \mathrm{~m}^{3} \mathrm{~m}^{-2}$ year $(0) \bigcirc \quad 0.5 \mathrm{~m}^{3} \mathrm{~m}^{-2}$ year $(1) \bigcirc \quad 0.25 \mathrm{~m}^{3} \mathrm{~m}^{-2}$ year $(2) \bigcirc$


reads together with the variables studied. TKN: total Kjeldahl nitrogen; OM: organic matter.

Table 3


slurry; P: planted; U: unplanted; 0, 1 and 2: 1.00, 0.50 and $0.25 \mathrm{~m}^{3} \mathrm{~m}^{-2}$ year, respectively; A and B: mesocosm replicates.

\begin{tabular}{|c|c|c|c|c|c|c|c|c|c|}
\hline & & & & \multicolumn{6}{|c|}{ Environmental Variable } \\
\hline & & & & Dilution & Location & $\mathrm{pH}$ & Humidity & Organic Matter & TKN \\
\hline \multirow[t]{2}{*}{ ANOVA } & & $\mathrm{CA}$ - CCA & $\mathrm{F}$ & 1.79 & 1.24 & 1.69 & 1.54 & 1.11 & 1.70 \\
\hline & & & $\operatorname{Pr}(>F)$ & $0.001^{\text {*N*k }}$ & 0.169 & $0.004^{* *}$ & $0.029^{*}$ & 0.359 & $0.007^{* *}$ \\
\hline \multirow{8}{*}{ MANOVA } & Unifrac metric & Weighted (quantitative) & $\mathrm{F}$ & 1.24 & 1.20 & 1.16 & 0.91 & 0.99 & 1.06 \\
\hline & & & $\operatorname{Pr}(>F)$ & $0.045^{*}$ & $0.034^{*}$ & 0.105 & 0.735 & 0.485 & 0.327 \\
\hline & & Unweighted (qualitative) & $\mathrm{F}$ & 1.08 & 1.36 & 1.02 & 0.96 & 0.96 & 1.01 \\
\hline & & & $\operatorname{Pr}(>F)$ & 0.287 & $0.008^{* *}$ & 0.285 & 0.73 & 0.692 & 0.351 \\
\hline & Ecological indexes & Morisita-Horn (quantitative) & $\mathrm{F}$ & 3.14 & 1.26 & 3.36 & 1.43 & 1.19 & 2.44 \\
\hline & & & $\operatorname{Pr}(>F)$ & $0.004^{* * *}$ & 0.255 & $0.002^{* * *}$ & 0.196 & 0.292 & $0.018^{*}$ \\
\hline & & Chao dissimilarity index (qualitative) & $\mathrm{F}$ & 2.96 & 3.31 & 3.22 & 2.14 & 0.37 & 7.18 \\
\hline & & 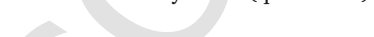 & $\operatorname{Pr}(>F)$ & 0.088 & $0.039^{*}$ & 0.054 & 0.158 & 0.685 & $0.002^{* * *}$ \\
\hline
\end{tabular}

* Significant variable at the level of $\mathrm{P}<0.05$; ** at the level of $\mathrm{P}<0.01$; *** at the level of $\mathrm{P}<0.001$.

\subsection{Bacterial community functional capabilities}

To estimate the composite metagenome the PICRUSt algorithm was applied providing the enzymatic activity relative frequencies using the KEGG Orthology codes (KOs). Results obtained from this effort exhibited a wide range of bacterial community genetic diversity, including those orthologous genes involved in the nitrogen cycle. A selection of $\mathrm{KO}$ codes and their relative abundances in the bacterial communities analysed is depicted in Fig. 6.

The K00401 KEGG ortholog ( $m c r B$; methyl-coenzyme M reductase beta subunit) which catalyses the last reaction of the methane synthesis was only present in the bacterial communities derived from the un- treated slurry. Methane and nitrous oxide comprise the main greenhouse gas emissions of untreated slurries; being these compounds responsible of discharging foul odour (Amon et al., 2006). Another fifteen KEGG orthologs were also mainly present in the untreated slurry and underrepresented or absent in the communities found in the treated slurry mesocosms.

The nitrogen removal process in constructed wetlands is extremely complex and includes ammonia volatilization, plant and bacterial uptake, adsorption, nitrification, denitrification, and anaerobic ammonia oxidation, among others (Vymazal, 2007).

The PICRUSt results showed than ammonification, nitrogen fixation and assimilatory nitrate reduction were the main bacterial community metabolisms detected in untreated swine slurry. On the other hand, 


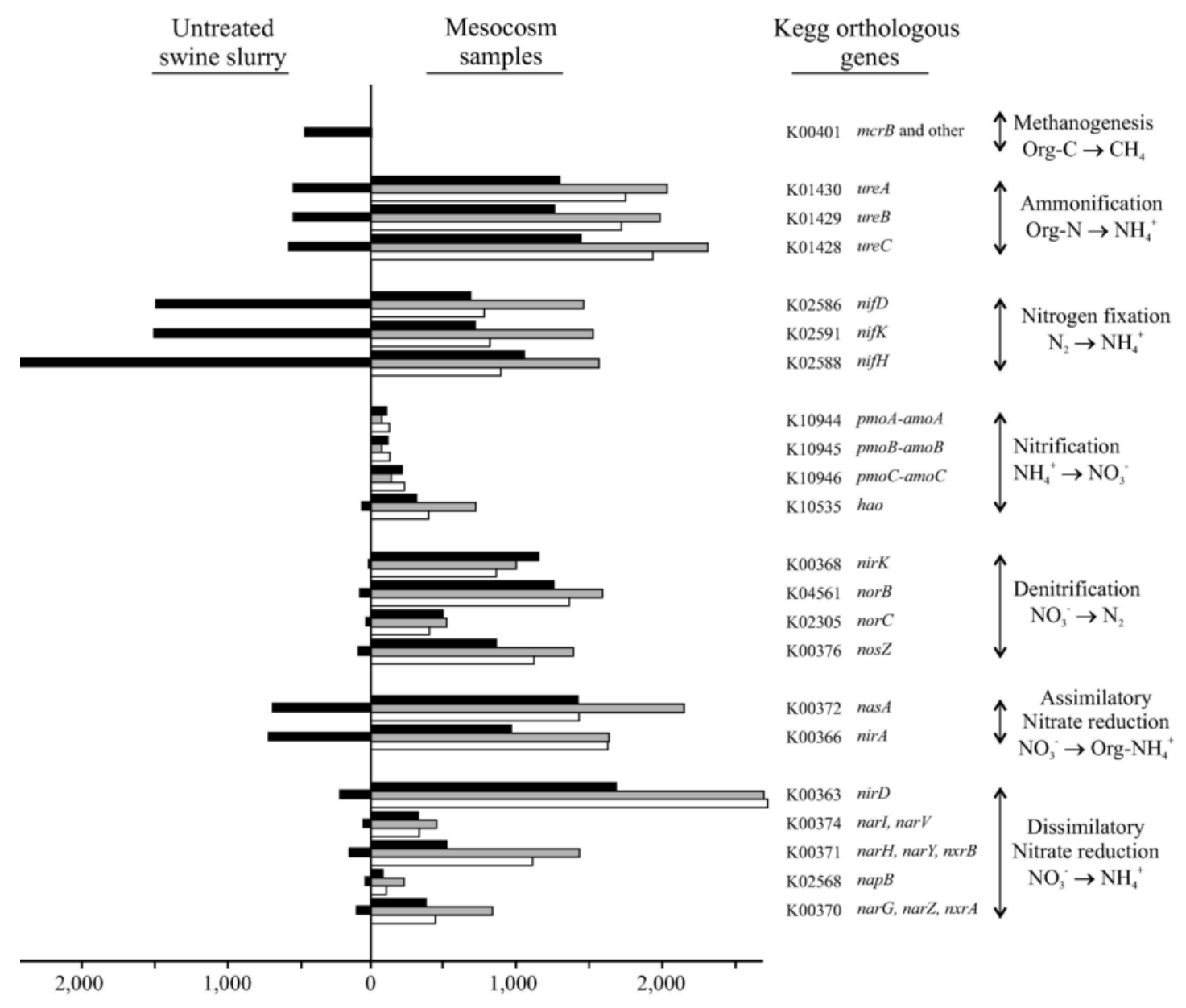

Relative abundance of gene function in 10,000 OTUs

Slurry hydraulic loading of mesocosms: $1 \mathrm{~m}^{3} \mathrm{~m}^{-2}$ year $(0) \bigcirc 0.5 \mathrm{~m}^{3} \mathrm{~m}^{-2}$ year $(1) \bigcirc 0.25 \mathrm{~m}^{3} \mathrm{~m}^{-2}$ year $(2) \bigcirc$

Fig. 6. Relative enzymatic activity abundance inferred in silico from the bacterial community 16S rRNA data. Enzymatic activities are coded with KEGG Orthologs.

communities from the mesocosms displayed lower nitrogen fixation gene functions, but higher ammonification and assimilatory nitrate reduction. Interestingly, no KEGG orthologs related to the anammox route were uncovered. Denitrification by anammox bacteria is partly responsible for the transformation of ammonia into nitrogen gas. In contrast, different authors have reported that total nitrogen removal in constructed wetlands is influenced primarily not only by amoA but also by anammox microbes (Zhi and Ji, 2014).

Baddam et al. (2016) quantified the urease activity in soils of two constructed wetlands treated with swine wastewater in order to estimate the ammonification process; they reported that the urease activity was strongly dependent on carbon and total nitrogen availability. Our study showed a high total nitrogen concentration of the untreated swine slurry (7789 $\left.\pm 623 \mathrm{mg} \mathrm{N} \mathrm{Kg}^{-1}\right)$, nevertheless, this nitrogen amount was mainly present in the form of ammonia $\left(6034 \pm 1306 \mathrm{mg} \mathrm{N} \mathrm{Kg}^{-1}\right)$. In other words, our results indicate that only the organic nitrogen (total Kjeldahl nitrogen minus ammonia), but not the total nitrogen, should be taken into account for this activity. As observed in Fig. 6, bacterial communities derived from the mesocosms were those that developed a higher urease activity compared to the bacterial communities arising from the untreated slurry.

Biological nitrification - denitrification is widely acknowledged as the major nitrogen removal mechanism (Chang et al., 2014). Nitrification implies a chemolithoautotrophic oxidation of ammonia into nitrate under strict aerobic conditions. In the mesocosm communities the rela- tive abundance of ammonia monooxigenase genes ( $a m o A, a m o B$ and amoC; K10944 to K10946 KEGG orthologs), linked to ammonia oxidizing bacteria, was lower than the genes linked to other nitrogen metabolisms. These genes were not detected in the untreated slurry. A low amoA presence and diversity in constructed wetlands has also been reported in other studies (Dong and Reddy, 2012). As suggested by Martens-Habbena et al. (2009), ammonia is the sole energy source for ammonia oxidizing bacteria and their growth rates are directly linked to ammonia availability and its oxidation kinetics. This statement is in accordance with our results, since the ammonia availability was low in all of the treated slurry mesocosms $\left(<120 \mathrm{mg} \mathrm{N} \mathrm{Kg}^{-1}\right.$ ), with a scarce presence of the ammonia oxidizing bacteria.

The biological denitrification mechanism makes use of nitrate as the terminal electron acceptor in low-oxygen environments. The relative abundance of KEGG orthologs related with denitrification functions was higher than genes related with nitrification. These denitrification genes were only present in the treated slurry mesocosms.

It has been considered that low ammonia and nitrate concentrations indicate that nitrification and denitrification are concurrently occurring in wetlands and that they are responsible of the high ammonia removal efficiency in constructed wetlands treated with swine slurry (Dong and Reddy, 2012). Moreover, it is regarded that microsites with steep oxygen gradients can be established, allowing sequential nitrification and denitrification to occur in a very close proximity to each other (Lee et al., 2009). 


\section{Conclusions}

The sludge treatment wetlands studied herein resulted in an overall TKN and $\mathrm{NH}_{4}{ }^{+}$decrease. A notable swine slurry treatment influence on the community composition was observed. Whereas the untreated pig slurry bacterial community was dominated by Firmicutes, Proteobacteria and Spirochaetes; Proteobacteria contributed most to the community composition of all the treated pig slurry samples.

Regarding richness, diversity and ordination of the studied communities, all of them evidenced a similar pattern, that is, profound differences between the untreated and treated swine slurry bacterial communities; and only slight differences among the treated swine slurry communities, enabling to identify two groups within the treated swine slurry communities, bacterial communities from the mesocosms receiving the highest hydraulic slurry loadings together with communities derived from the remaining mesocosms. Besides of the treatment and hydraulic loading influences, our results have indicated that the $\mathrm{pH}$ emerged as an important predictor of the community composition, diversity and ordination.

Finally, the composite metagenome results disclosed a wide genetic diversity range. All nitrogen cycle metabolic pathways were included in the mesocosm communities, with the anammox route as the only exception. Ammonification and assimilatory nitrate reduction were the most commonly detected nitrogen pathways in treated swine slurry.

All these findings have provided insight into the bacterial community structure and diversity of untreated and treated swine slurry in sludge treatment wetlands, allowing also to identify those environmental variables related to the wetland design that shaped the bacterial community assembly of the different experimental mesocosms.

\section{Uncited references}

McArdle and Anderson (2001).

\section{References}

Ahn, C., Gillevet, P.M., Sikaroodi, M., 2007. Molecular characterization of microbial communities in treatment microcosm wetlands as influenced by macrophytes and phosphorus loading. Ecol. Ind. 7, 852-863.

Ahn, C., Peralta, R.M., 2009. Soil bacterial community structure and physicochemical properties in mitigation wetlands created in the Piedmont region of Virginia (USA). Ecol. Eng. 35, 1036-1042.

Amon, B., Kryvoruchko, V., Amon, T., Zechmeister-Boltenstern, S., 2006. Methane, nitrous oxide and ammonia emissions during storage and after application of dairy cattle slurry and influence of slurry treatment. Agric. Ecosyst. Environ. 112, 153-162.

Ansola, G., Arroyo, P., Sáenz de Miera, L.E., 2014. Characterization of the soil bacterial community structure and composition of natural and constructed wetlands. Sci. Total Environ. 473-474, 63-71.

APHA, 2005. Standard Methods for the Examination of Water and Wastewater, 21st ed. American Public Health Association, Washington, DC, USA, 1368.

Baddam, R., Reddy, G.B., Raczkowski, C., Cyrus, J.S., 2016. Activity of soil enzymes in constructed wetlands treated with swine wastewater. Ecol. Eng. 91, 24-30.

Bartram, A.K., Jiang, X., Lynch, M.D.J., Masella, A.P., Nicol, G.W., Dushoff, J., Neufeld, J.D., 2014. Exploring links between $\mathrm{pH}$ and bacterial community composition in soils from the Craibstone Experimental Farm. FEMS Microbiol. Ecol. 87, 403-415.

Bunton, B., O'Shaughnessy, P., Fitzsimmons, S., Gering, J., Hoff, S., Lyngbye, M., Thorne, P.S., Wasson, J., Werner, M., 2007. Monitoring and modeling of emissions from concentrated animal feeding operations: overview of methods. Environ. Health Perspect. 115 (2), 303-307.

Calheiros, C.S.C., Rangel, A.O.S.S., Castro, P.M.L., 2007. Constructed wetland systems vegetated with different plants applied to the treatment of tannery wastewater. Water Res. 41, 1790-1798.

Caporaso, J.G., Kuczynski, J., Stombaugh, J., Bittinger, K., Bushman, F.D., Costello, E.K., Fierer, N., Gonzalez Peña, A., Goodrich, J.K., Gordon, J.I., Huttley, G.A., Kelley, S.T., Knights, D., Koenig, J.E., Ley, R.E., Lozupone, C.A., McDonald, D., Muegge, B.D., Pirrung, M., Reeder, J., Sevinsky, J.R., Yatsunenko, T., Zaneveld, J., Knight, R., 2010. QIIME allows analysis of high-throughput community sequencing data. Nat. Methods 7 (5), 335-336.

Chang, Y., Wu, S., Zhang, T., Mazur, R., Pang, C., Dong, R., 2014. Dynamics of nitrogen transformation depending on different operational strategies in laboratory-scale tidal flow constructed wetlands. Sci. Total Environ. 487, 49-56.
Cole, J.R., Wang, Q., Cardenas, E., Fish, J., Chai, B., Farris, R.J., Kulam-Syed-Mohideen, A.S., McGarrell, D.M., Marsh, T., Garrity, G.M., Tiedje, J.M., 2008. The Ribosomal Database Project: improved alignments and new tools for rRNA analysis. Nucl. Acids Res. 37, 141-145.

Cole, J.R., Wang, Q., Fish, J.A., Chai, B., McGarrell, D.M., Sun, Y., Brown, C.T., Porras-Alfaro, A., Kuske, C.R., Tiedje, J.M., 2014. Ribosomal Database Project: data and tools for high throughput rRNA analysis. Nucl. Acids Res. 42, 633-642.

Cook, K.L., Rothrock, M.J., Lovanh, N., Sorrell, J.K., Loughrin, J.H., 2010. Spatial and temporal changes in the microbial community in an anaerobic swine waste treatment lagoon. Anaerobe 16, 74-82.

Dong, X., Reddy, G.B., 2012. Ammonia-oxidizing bacterial community and nitrification rates in constructed wetlands treating swine wastewater. Ecol. Eng. 40, 189-197.

Edgar, R.C., 2010. Search and clustering orders of magnitude faster than BLAST. Bioinformatics 26 (19), 2460-2461.

Edgar, R.C., Hass, B.J., Clemente, J.C., Quince, C., Knight, R., 2011. UCHIME improves sensitivity and speed of chimera detection. Bioinformatics 27 (16), 2194-2200.

Edwards, J.K., Gray, K.R., Cooper, D.J., Biddlestone, A.J., Willoughby, N., 2001. Reed bed dewatering of agricultural sludges and slurries. Water Sci. Technol. 44 (11-12), 551-558.

Giácoman-Vallejos, G., Ponce-Caballero, C., Champagne, P., 2015. Pathogen removal from domestic and swine wastewater by experimental constructed wetlands. Water Sci. Technol. 71 (8), 1263-1270.

Giraldi, D., Iannelli, R., 2009. Short-term water content analysis for the optimization of sludge dewatering in dedicated constructed wetlands (reed bed systems). Desalination 246, 92-99.

Harrington, C., Scholz, M., Culleton, N., Lawlor, P.G., 2012. The use of integrated constructed wetlands (ICW) for the treatment of separated swine wastewaters. Hydrobiologia 692, 111-119.

Hwang, O.H., Raveendar, S., Kim, Y.J., Kim, J.H., Kim, T.H., Choi, D.Y., Jeon, C.O., Cho, S.B., Lee, K.T., 2014. Deodorization of pig slurry and characterization of bacterial diversity using 16S rDNA sequence analysis. J. Microbiol. 52 (11), 918-929.

Inceoglu, O”, Al-Soud, W.A., Salles, J.F., Semenov, A.V., van Elsas, J.D., 2011. Comparative analysis of bacterial communities in a potato field as determined by pyrosequencing. PLoS ONE 6 (8), 1-11.

Isaacson, R., Kim, H.B., 2012. The intestinal microbiome of the pig. Animal Health Res. Rev. 13 (1), 100-109.

Kengne, I.M., Kengne, E.S., Akoa, A., Bemmo, N., Dodane, P.H., Koné, D., 2011. Vertical-flow constructed wetlands as an emerging solution for faecal sludge dewatering in developing countries. J. Water Sanitation Hyg. Dev. 1 (1), 13-19.

Kumar, S., Stecher, G., Tamura, K., 2016. MEGA7: Molecular Evolutionary Genetics Analysis version 7.0 for bigger datasets. MBE Advance Access 1-11.

Kumari, P., Choi, H.L., Sudiarto, S.I.A., 2015. Assessment of bacterial community assembly patterns and processes in pig manure slurry. PLoS ONE 30, 1-12.

Langille, M.G.I., Zaneveld, J., Caporaso, J.G., Mcdonald, D., Knights, D., Reyes, J.A., Clemente, J.C., Burkepile, D.E., Vega Thurber, R.L., Knight, R., Beiko, R.G., Huttenhower, C., 2013. Predictive functional profiling of microbial communities using 16S rRNA marker gene sequences. Nat. Biotechnol. 31 (9), 814-821.

Lee, C., Fletcher, T.D., Sun, G., 2009. Nitrogen removal in constructed wetland systems. Eng. Life Sci. 1, 11-22.

Lozupone, C., Knight, R., 2005. UniFrac: a new phylogenetic method for comparing microbial communities. Appl. Environ. Microbiol. 71 (12), 8228-8235.

Martens-Habbena, W., Berube, P.M., Urakawa, H., de la Torre, J.R., Stahl, D.A., 2009. Ammonia oxidation kinetics determine niche separation of nitrifying Archaea and Bacteria. Nature 461, 976-981.

McArdle, B.H., Anderson, M.J., 2001. Fitting multivariate models to community data: a comment on distance-based redundancy analysis. Ecology 82 (1), 290-297.

McDonald, D., Price, M.N., Goodrich, J., Nawrocki, E.P., DeSantis, T.Z., Probst, A., Andersen, G.L., Knight, R., Hugenholtz, P., 2012. An improved Greengenes taxonomy with explicit ranks for ecological and evolutionary analyses of bacteria and archaea. Int. Soc. Microbial Ecol. 6, 610-618.

Ministerio de Agricultura, Pesca y Alimentación, 1994. Métodos oficiales de análisis. Tomo III. Secretaría General de Alimentación, Madrid, Spain.

Molleda, P., Blanco, I., Ansola, G., de Luis, E., 2008. Removal of wastewater pathogen indicators in a constructed wetland in Leon, Spain. Ecol. Eng. 33, 252-257.

Nielsen, S., 2003. Sludge drying Reed beds. Water Sci. Technol. 48, 101-109.

Nielsen, S., 2007. Helsinge sludge reed bed system - reduction of pathogene microorganisms. Water Sci. Technol. 56, 175-182.

Nielsen, S., Larsen, J.D., 2016. Operational strategy, economic and environmental performance of sludge treatment reed bed systems-based on 28 years of experience. Water Sci. Technol. 74 (8), 1793-1799.

Oksanen, J., Blanchet, F.G., Kindt, R., Legendre, P., O'Hara, R.B., Simpson, G.L., et al. Vegan: community ecology package. $\mathrm{R}$ package version 1.17-4, 2010.

Palmer, M.W., 1993. Putting things in even better order: the advantages of canonical correspondence analysis. Ecology 74 (8), 2215-2230.

Paradis, E., Calude, J., Strimmer, K., 2004. APE: analyses of phylogenetics and evolution in R language. Bioinformatics 20 (2), 289-290.

Peralta, R.M., Ahn, C., Gillevet, P.M., 2013. Characterization of soil bacterial community structure and physicochemical properties in created and natural wetlands. Sci. Total Environ. 443, 725-732.

Preiss, L., Hicks, D.B., Suzuki, S., Meier, T., Krulwich, T.A., 2015. Alkaliphilic bacteria with impact on industrial applications, concepts of early life forms, and bioenergetics of ATP synthesis. Front. Bioeng. Biotechnol. 3 (75), 1-16.

R Core Team, 2016. R: A language and environment for statistical computing. R Foundation for Statistical Computing, Vienna, Austria. URL https://www.R-project.org/. 
Sáenz de Miera, L.E., Arroyo, P., de Luis Calabuig, E., Ansola, G., 2016. Effects of varying $\mathrm{CO}_{2}$ flows on bacterial communities in mesocosms created from two soils. Int. J. Greenhouse Gas Control 46, 205-214.

Scholss, P.D., Westcott, S.L., Ryabin, T., Hall, J.R., Hartmann, M., Hollister, E.B., Lesniewski, R.A., Oakley, B.B., Parks, D.H., Robinson, C.J., Sahl, J.W., Stress, B., Thallinger, G.G., Van Horn, D.J., Weber, C.F., 2009. Introducing mothur: open-source, platform-independent, community-supported software for describing and comparing microbial communities. Appl. Environ. Microbiol. 75 (23), 7537-7541.

Snell-Castro, R., Godon, J.J., Delgenès, J.P., Dabert, P., 2005. Characterisation of the microbial diversity in a pig manure storage pit using small subunit rDNA sequence analysis. FEMS Microbiol. Ecol. 52, 229-242.

Stefanakis, A.I., Tsihrintzis, V.A., 2012. Effect of various design and operation parameters on performance of pilot-scale Sludge Drying Reed Beds. Ecol. Eng. 38, 65-78.

Vázquez, M.A., de la Varga, D., Plana, R., Soto, M., 2013. Vertical flow constructed wetland treating high strength wastewater from swine slurry composting. Ecol. Eng. 50, $37-43$.
Vymazal, J., 2007. Removal of nutrients in various types of constructed wetlands. Sci. Total Environ. 380, 48-65.

Wang, Q., GArrity, G.M., Tiedje, J.M., Cole, J.R., 2007. Naïve Bayesian classifier for rapid assignment of rRNA sequences into the new bacterial taxonomy. Appl. Environ. Microbiol. 73 (16), 5261-5267.

Xian, Q., Hu, L., Chen, H., Chang, Z., Zou, H., 2010. Removal of nutrients and veterinary antibiotics from swine wastewater by a constructed macrophyte floating bed system. J. Environ. Manage. 91, 2657-2661.

Zhi, W., Ji, G., 2014. Quantitative response relationships between nitrogen transformation rates and nitrogen functional genes in a tidal flow constructed wetland under $\mathrm{C} / \mathrm{N}$ ratio constraints. Water Res. 64, 32-41. 